\title{
Airport competition in Brazil's northeast region
}

\author{
Competição aeroportuária no nordeste do Brasil \\ Competencia aeropuerto en el nordeste de Brasil
}

Received: 01/03/2021 | Reviewed: 01/13/2022 | Accept: 01/21/2022 | Published: 01/23/2022

\author{
Maria Cecília de Farias Domingos \\ ORCID: https://orcid.org/0000-0001-7714-393X \\ Aeronautic Institute of Technology, Brazil \\ E-mail: mceciliadomingos@hotmail.com \\ Viviane Adriano Falcão \\ ORCID: https://orcid.org/0000-0003-0850-4281 \\ Federal University of Pernambuco, Brazil \\ E-mail: viviane.afalcao@ufpe.br \\ Francisco Gildemir Ferreira da Silva \\ ORCID: https://orcid.org/0000-0002-5890-3769 \\ Federal University of Ceará, Brazil \\ E-mail: gildemir@ufc.br
}

\begin{abstract}
Aviation growth is mainly due to the integration between national and world economies in the global era. The capital's airports of the Brazilian Northeast were managed by a federal public company and are currently being granted to private companies, which have the premise of expanding the number of passengers. The increase in number of passengers drives competition between airports, since they must have adequate infrastructure to contain the demand. The choice by the user for an airport can be evaluated based on factors such as access mode, air fares, availability of flights and airport infrastructure. This paper aims at evaluating the choice of passengers between two airports in the Northeast of Brazil since 2014 and how this choice has been changing over the years. The binomial logit model was used to obtain the probability of choosing between airports and to evaluate the most relevant factors. The results of the study presented that availability for direct flights, preference for airlines, access time, air fares and general satisfaction of the airport fluctuated in the choice of the two airports during the study period. By evaluating the likelihood of choice, subsidies are provided to improve services considered indispensable by passengers.
\end{abstract}

Keywords: Airport; Choice; Passenger; Binomial logit.

\section{Resumo}

$\mathrm{O}$ crescimento da aviação deve-se principalmente à integração entre as economias nacional e mundial na era global. Os aeroportos da capital nordestina eram administrados por uma empresa pública federal e atualmente estão sendo concedidos a empresas privadas, que têm a premissa de ampliar o número de passageiros. O aumento do número de passageiros impulsiona a competição entre os aeroportos, uma vez que eles devem ter infraestrutura adequada para conter a demanda. A escolha do aeroporto pelo usuário pode ser avaliada com base em fatores como modo de acesso, tarifas aéreas, disponibilidade de voos e infraestrutura aeroportuária. Este trabalho tem como objetivo avaliar a escolha dos passageiros entre dois aeroportos no Nordeste do Brasil desde 2014 e como essa escolha vem mudando ao longo dos anos. O modelo logit binomial foi utilizado para obter a probabilidade de escolha entre aeroportos e avaliar os fatores mais relevantes. Os resultados do estudo mostraram que a disponibilidade para voos diretos, preferência por companhias aéreas, tempo de acesso, tarifas aéreas e satisfação geral do aeroporto flutuaram na escolha dos dois aeroportos durante o período de estudo. Ao avaliar a probabilidade de escolha, são fornecidos subsídios para a melhoria dos serviços considerados indispensáveis pelos passageiros.

Palavras-chave: Aeroporto; Escolha; Passageiro; Logit binomial.

\section{Resumen}

El crecimiento de la aviación se debe principalmente a la integración entre la economia nacional y mundial en la era global. Los aeropuertos de las capitales del Nordeste brasileño eran administrados por una empresa pública federal y actualmente están siendo otorgados a empresas privadas, que tienen como premisa ampliar el número de pasajeros. El aumento en el número de pasajeros impulsa la competencia entre aeropuertos, ya que deben contar con la infraestructura adecuada para hacer frente a la demanda. La elección de un aeropuerto por el usuario puede evaluarse en función de factores como el modo de acceso, las tarifas aéreas, la disponibilidad de vuelos y la infraestructura del aeropuerto. Este documento tiene como objetivo evaluar la elección de pasajeros entre dos aeropuertos en el Nordeste de Brasil desde 2014 y cómo esta elección ha ido cambiando a lo largo de los años. Se utilizó el modelo logit binomial para obtener la probabilidad de elegir entre aeropuertos y evaluar los factores más relevantes. Los resultados del 
estudio mostraron que la disponibilidad para vuelos directos, preferencia por aerolíneas, tiempo de acceso, tarifas aéreas y satisfacción general del aeropuerto fluctuaron en la elección de los dos aeropuertos durante el período de estudio. Al evaluar la probabilidad de elección, se otorgan subsidios para mejorar los servicios considerados indispensables por los pasajeros.

Palabras clave: Aeropuerto; Elección; Pasajero; Logit binomial.

\section{Introduction}

Air transport is constantly growing (ICAO, 2018; SAC, 2020) when compared to other modes, and it is the mode of transport that, when the economy develops in the country, intensifies demand and investments in the sector. Competition between airports can occur due to the expansion of globalization and privatization, the emergence of airlines that operate with the policy of low cost - low fare and improvements in accessibility (Murça \& Correia, 2013). According to Jimenez et al. (2014), globalization comes from the rise of the era of economic deregulation, which promotes competition between airports for services offered in a global proportion, mainly in the management and consultancy sector, or through the acquisition of other airports or parts of them.

In recent decades, economic liberalization has favored the transfer of domain, management and operation of airports, in which many have been privatized or operate for the purpose of trade (Jimenez, 2014). For Jarach (2001), the ideals of airports have been changing, with the objective of attending various demand groups with a variety of proposals available (e.g. existence of commercial establishments, consultancy services and facilities for events).

For the passenger, the airport choice mainly involves access time to the airport, flight frequency and air fare (Harvey, 1987; Ashford \& Bencheman, 1988; Hess; Polak, 2005; Murça \& Correia, 2013; Paliska et al., 2016). However, other aspects such as time and duration of travel, choice of airline and mode of access are also relevant (Murça; Correia, 2013). The research conducted by Loo (2008), when studying airport competition in the Hong Kong-Pearl River Delta, China, showed that air fare, access time, flight frequency and choice by airline were significant factors in the decision by an air terminal. Bao et al. (2016) indicate that accessibility is vital in attracting passengers, being an important factor in stimulating competition between airports.

It is known that airports have been developing with attributes that belong to different levels or fields, establishing them as distinct global entities (Kalakou \& Macário, 2013). Competition promotes improvements in infrastructure and services, and the importance of analyzing the attributes of choice for travelers becomes essential in the study. The biggest challenges are related to growth and improvements in services, and airport operators are responsible for successfully lead this fact (Windle \& Dresner, 1995; Kalakou \& Macário, 2013).

Until the end of the 1980s, airports were seen as service providers that owned airlines and passengers (Tretheway \& Kincaid, 2005). The most important Brazilian airports were almost entirely operated by the public company INFRAERO, and therefore, competition between airports was practically non-existent. With the strengthening of transport infrastructure concession policies, including airports, structural changes occurred in the sector, favoring competition between airport operating companies.

According to Tretheway and Kincaid (2005), airports that manage to enhance passenger facilitation processes to reduce connection times and enable a faster throughput are able to improve their competitive position and attract passengers. The tendency is for airport operators to look for ways to attract more passengers to their terminals, with new partnerships between airlines to promote benefits in connections between flights and the introduction of technologies that promotes the speed on ticket purchase and passengers' boarding and landing and reduce the time of the aircraft on the ground.

Airports are two-sided markets, in which the operators need to conquer more than one type of customer, as they need each other in order to enhance the service. Airlines value airports with high passenger demand and passengers value the airport 
for having a variety of airlines and destinations. Likewise, if rental prices charged to airport retailers were to increase, many facilities would probably close and so many passengers would stop choosing the airport as a starting point since it would no longer be so attractive. This reduces airline ticket sales, generating a multiplier effect that will affect passenger demand (Gatwick Airport, 2010).

Therefore, airports must invest in their two groups of customers: passengers and airlines. The two-sided platform is able to explore the interdependence between two or more customers and evaluate measures for network actions to take place, hence promoting the airport's performance (Bettini \& Oliveira, 2016). Competition between airports can lead to higher service prices, since high rates directly influence the value attributed by market share across the platform, including airlines and passengers (Gatwick Airport, 2010).

The rise in attending the needs of passengers promotes improvement in airport management and expansion in the number of airports in the world. The study of competition between airports seeks to explain which circumstances prompt the choice of an airport by the passengers, mostly in the Northeast region of Brazil, where there are four different operators at its main airports. For the study, the International Airports of Recife (REC) and Natal (NAT) were chosen for the analysis of the airport choice, due to two main factors: concession period and demand growth. NAT was granted in 2011, with the construction of its terminal in 2012 and the start of operations in 2014 whilst REC was granted solely in 2019, starting operations in 2020. However, the demand for passengers in NAT did not show expected growth over the years while REC showed an increase in movement in the same period (ANAC, 2019a; Website Hórus, 2019a).

\subsection{Multiple Airport Region}

A multiple airport region (MAR) is composed of more than one airport operating in the analysis area. Airport choice by passengers in a MAR is a topic widely studied by several authors (Harvey, 1987; Ashford; Bencheman, 1988; Loo, 2008; de Luca, 2012; Paliska et al., 2016; Bao et al., 2016; Muñoz et al., 2017). The common findings of these studies show that airport access time and air fare are one of the dominant factors, although their importance varies depending on the group of passengers. However, according to Jimenez et al. (2014), competition at airports is a recent topic among researchers, but there are fundamentals about how competition arose. There are several factors for this, such as, overlapping the catchment area and the choice of hubs by the airlines.

Competition from airports that are in the same catchment area may arise from elements such as the number of destinations offered by the airport, accessibility, low fares and passengers' preference based on location, cost of travel time, flight times and available services (Jimenez et al., 2014; Cheung et al., 2020). The catchment area of each airport is also a relevant factor since it promotes the installation of hubs by airlines. Airlines are important in defining the flight networks offered by the airport, which attracts passengers and services (Jimenez et al., 2014).

The competitive opportunities offered by deregulation favored a change in the business models adopted by airports. Many have developed themselves through more sophisticated services, with the evolve of a network of competence, mainly in the marketing sector and the quality of services (Pagliari \& Graham, 2019). Airports have different services characteristics, passenger assistance and communication channels.

Airports with high traffic levels and which are considered to have primary and secondary hubs have business models with similar approaches, since they are aimed at all passenger transport segments and have communication channels to reach users about their products and services (Kalakou \& Macário, 2013). The elements can be adopted by other airports that acquire the same business category, such as airports of primary and secondary hubs, businesses, cargo and low-cost (Kalakou \& Macário, 2013). It is assumed that the impact on activities and resources operated by airports of the same category and which are in the same catchment area can generate competition strategies. 
Passengers' attractiveness is related to airports that provide accessibility and direct connections between cities. For Skinner (1976), improvements in airport access are more relevant in the choice of the airport among passengers than flight flexibility. Additionally, the cost and quality of the service level offered by an airport impact the attractiveness as a starting destination (Tretheway \& Kincaid, 2005; Lieshout, 2012; Prentice \& Kadan, 2019). Airports compete with other transport, such as private cars and road buses, having a significant impact on the demand for airports (Jimenez et al., 2014). As air transport requires integration between the other modes, a region with more options for transport modes to the airport may have supremacy in the final choice.

The catchment area embodied by NAT and REC can be considered a MAR. In the northeast of Brazil, there are hypotheses that airports compete mainly due to accessibility and the flight frequency. It is assumed that there are national airports far from urban centers and, therefore, there is a preference for passengers to travel to airports in other states to start the air route.

The airport industry currently faces a competitive scenario and the need to embrace more customers is a frequent situation. For Windle and Dresner (1995) and Pels et al. (2001), access time and frequency of flights are fundamental factors for choosing an airport in a MAR. When carrying out a joint analysis of all factors, the process of adapting airports to the situation becomes more real. To fulfill the passengers demand, airport must have competent professionals who introduce effective administration, winning over users who are increasingly looking for credibility and reliability in the sector.

\subsection{Discrete Choice Models}

It is necessary to use tools that allow to evaluate the users' behavior in face of the numerous competitive scenarios of the air modal. Murça and Correia (2013) carried out a comparative analysis between seven studies on this theme, with the analysis by the mathematical models, such as multinomial logit, nested logit and probit. It was found that most of the studies evaluated indicated three main variables in airport choice: time of access to the airport, flight frequency and air fare (Murça \& Correia, 2013).

Windle and Dresner (1995) analyzed the choice of airports in the Washington, DC/Baltimore area based on passengers traveling to the region's most popular domestic destinations. The data were obtained through questionnaires filled out by passengers which contained questions about the destination of the trip, the purpose of the journey, the mode of access and the first reason for choosing that airport. By means of the multinomial logit model, the research revealed that the most relevant variables in the choice were access time and flight frequencies, especially for passengers traveling with business purposes (Windle \& Dresner, 1995).

De Luca (2012) used the multinomial logit, nested logit and the mixed multinomial logit to assess the airport choice in the Campania region, in southern Italy. Despite the regional capital Naples be a populous region, travelers often experience high air fares and low flight frequencies at Naples-Capodichino Airport. Consequently, passengers have two other airports as an alternative: Roma Fiumicino and Roma Ciampino. In conlusion, although the Naples-Capodichino Airport has better accessibility, high air fares can reduce the choice of passengers for its terminal. As a recommendation, Naples Airport should give importance to the value of the airport tax, airfare and parking fee in order to be able to compete with other airports. Rome airports have better frequencies compared with Naples one, but they have less accessibility, which allows a reduction in the choice of passengers. Thus, it is said that access time is the factor most likely to shift travel demand from one airport to another, and certainly, capable to influence the choice of a terminal by travelers. The results suggest that, in order to Naples not lose demand, it needs to keep reinforcing its accessibility, through transit improvement (de Luca, 2012).

Utility theory is the form of study in which the choice of a modality with the highest rate of advantage among the others is evaluated. This theory is based on the attributes and understanding of individuals, in which the degree of user 
satisfaction from the choice is associated (Negri et al., 2019). According to Murça and Correia (2013), for each probability of choosing brand $\mathrm{j}$ in relation to a group of alternatives, the decision maker i establishes a Uij utility, which it is composed by the observed characteristics Vij and the unobserved Eij, as seen in Equation 1 (Ben-Akiva \& Lerman, 1985). The systematic component Vij depends on the characteristics of alternatives $\mathrm{Xij}$ and consumers $\mathrm{Zi}$, as seen in Equation 2.

$$
\begin{gathered}
U i j=V i j+\varepsilon i j \\
V i j=f(X i j, Z i)
\end{gathered}
$$

The existence of the random component $\varepsilon \mathrm{ij}$ occurs due to the fact that individuals exhibit inconsistency in their choices. According to Negri et al. (2019), this component is composed of factors that affect utility, but are not identified by the model analyst.

The logit is known to be the simplest and most used in transport choice research. It follows a Gumbel distribution and considers that the unobserved values $\mathrm{Eij}$ of the utility function are independent and distributed equally to all users (Train, 2003). According to Ben-Akiva and Lerman (1985), the expression is described as seen in Equation 3.

$$
P i=\frac{e^{U i}}{\sum_{j=1}^{n} e^{U i}}
$$

In binary models, as is the case with binomial logit, the main objective is to assess the probability between two alternatives existing in a sample, in which the alternatives can be quantitative or qualitative (Negri et al., 2019).

\section{Methodology}

The study used the qualitative technique approach, with a case study for two airports in Brazil, according to the methodology pointed out by Pereira et al. (2018). The case study makes it possible to contribute with data and relevant information on a topic in order to increase knowledge in the area, and thus allowing for improvements (Pereira et al., 2018). Two northeastern airports were chosen for the study: The International Airports of Natal (NAT) and Recife (REC). The objective of the study is to assess competition for passengers between these terminals from 2014 to 2019, mainly because, after certain periods, they have been under the administration of private operators, which it is an essential factor in the competition between them. According to Paliska et al. (2016), the airport's catchment area may change over time. An OD survey carried out by EPL (2015) revealed that in 2014, about 10\% of the passengers surveyed at REC took more than 3h30min to arrive at the terminal. The PAN (2019) confirmed that almost $70 \%$ of passengers originating in NAT want to visit cities in the state of Rio de Janeiro or São Paulo, and that in April 2018 (SIROS, 2020) the direct flights to the main airports in these states were 1.076 for REC and 337 for NAT. The choice to study these airports was based on factors such as: concession to private companies, location, annual passenger movements and airport growth.

Figure 1 shows the position of airports in the country, with a distance between them in a straight line of 265 kilometers. 
Figure 1: Straight line distance between two northeastern airports in Brazil.

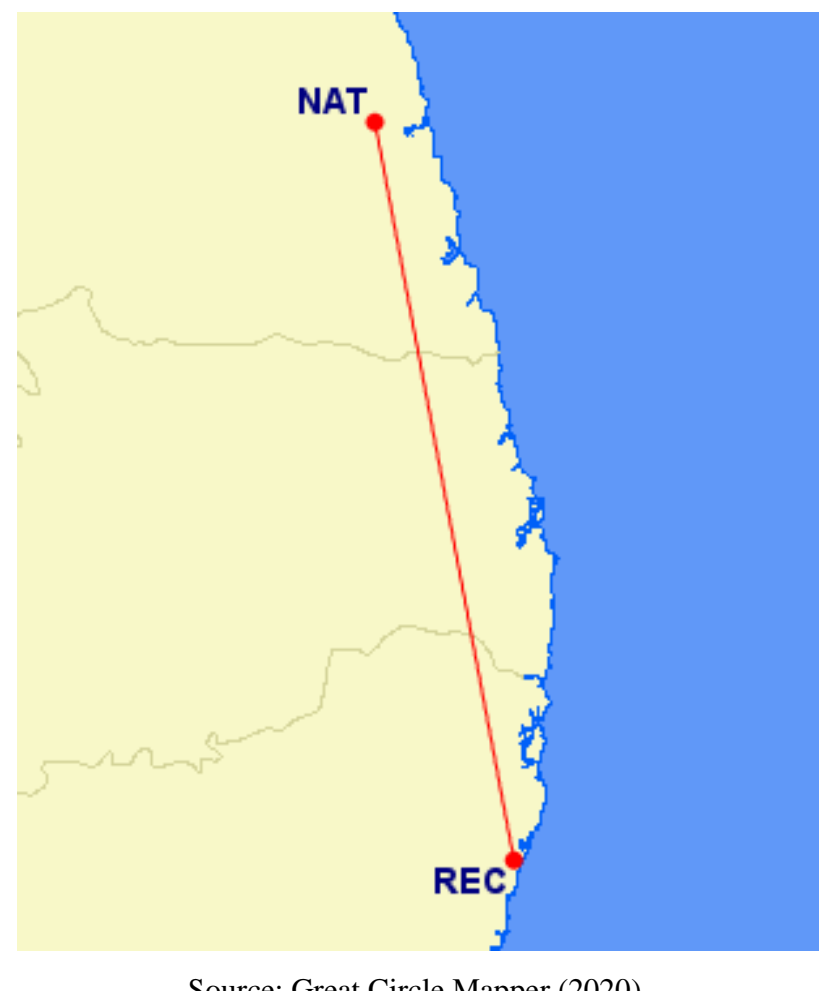

Source: Great Circle Mapper (2020).

NAT is located in São Gonçalo do Amarante, which is far 33 kilometers from the center of Natal, the capital of the state of Rio Grande do Norte (Inframerica, 2020). Its terminal is administered by Inframérica Consorcium and had been the first in the country to be granted to the private sector, for a period of 28 years (ANAC, 2019a). There are three national airlines and one international in operation (Inframerica, 2020).

REC is 11 kilometers far from the center of the capital of the state of Pernambuco (Aena Brasil, 2020). Its terminal was granted en bloc in 2019 to the Spanish operator Aena Desarrollo Internacional for 30 years (ANAC, 2019a). There are three national airlines in operation and four internationals. The airport is the national hub of Azul Brazilian Airlines, providing connection exclusively from the terminal to all capitals of the Brazilian Northeast (Aena Brasil, 2020).

Figure 2 shows a comparative analysis of passengers' movement from the two airports between the six years of study. NAT started its commercial operations in 2014, registering 1,478,903 passengers, between departures and arrivals. In 2015, NAT showed a significant growth, with 62.8\% more movement compared to the previous year. From 2016 to 2018, REC and NAT showed a significant increase in demand, with growth of $12 \%$ and $4 \%$, respectively. In 2019, REC increased $3.50 \%$ in passengers, compared to 2018, whilst NAT lost demand. In 2019, REC reached 8.6 million passengers and NAT, 2.2 million (Website Hórus, 2019a). 
Figure 2: Annual movement of regular passengers, composed by departures and arrivals.

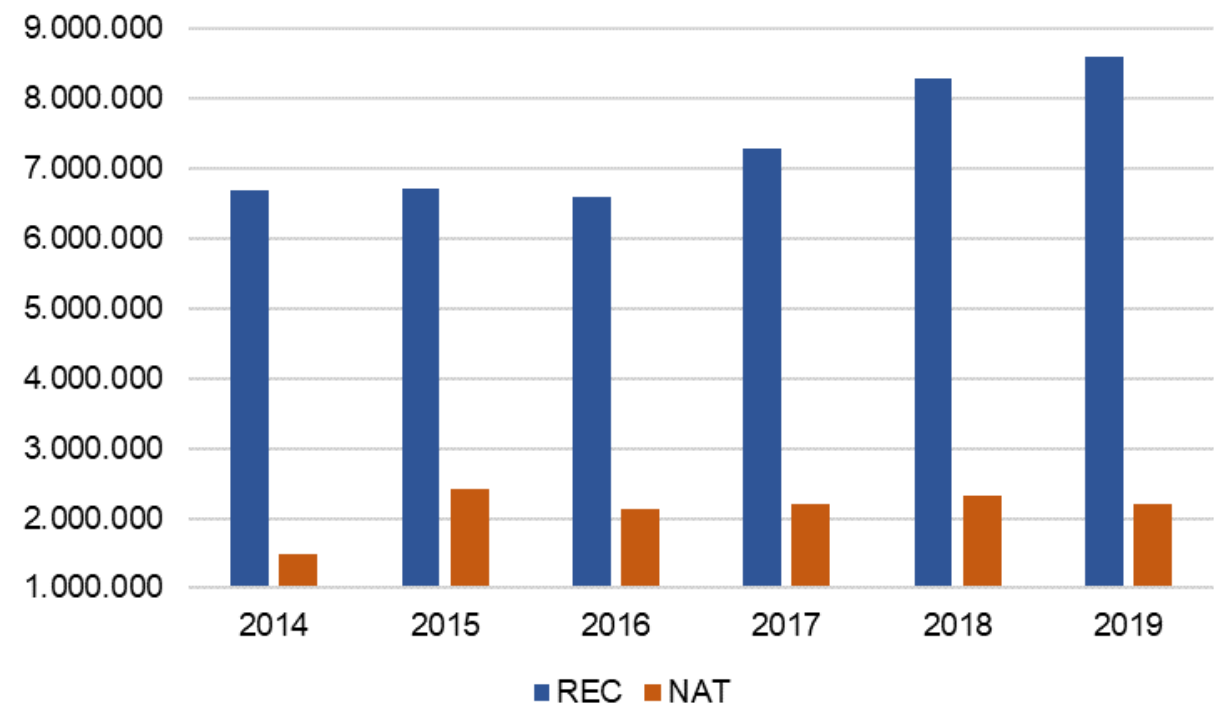

Source: Website Hórus (2019a).

The database and variables are used in order to identify the reasons for airport choice through the Revealed Preference Technique, in which passengers state the reasons for choosing the trip that was taking place at the time of the interview. The study consists of analyzing the questionnaire carried out by the Civil Aviation Secretariat (SAC), with the last update in November 2019 (Website Hórus, 2019b). The questionnaire used consists of four parts, where there are data on the airline, passenger profile, characteristics of access to the airport and notes regarding the level of satisfaction of the services available. Additionally, the variable monthly average air fare per airline was introduced, using retrospective data from ANAC (ANAC, 2019b).

The questionnaire data is taken into account for those passengers who started the flight at any of the two airports, thus excluding those who were in flight connection or landing at the time of the interview.

The data taken from the questionnaire conducted by SAC covers a period between June/2014 and November/2019 and reached 12,225 passengers. It is known that 7,344 came from REC and 4,881 from NAT. For passengers with business-related reasons for travel, 3,279 started flights in REC and 595 in NAT.

Regarding the explanatory variables, five were used: time of access, air fare, frequency of flights, degree of satisfaction of the airport and preference for airline. Solely domestic flights were counted, and four nationals air companies were included.

The access time to the airport was computed, with a variation between up to 60 and up to 210 minutes. The data obtained are related to the time before arrival at the airport by the interviewee, not promoting accuracy in the answer regarding the supposed time of access to the airport, since many may have arrived hours before the flight.

The airport's overall satisfaction level has a scale ranging from 1 to 5. Flight frequency as a reason for choice was estimated using two dummies variables, which were characterized as "it is the airport that has a direct flight to the destination" and "it is the airport that despite having air connections, it is the one that has the best flight dates/hours". These variables do not measure the frequency of the flights themselves, but how the opportunity for flights without connections can be seen as a reason for choice.

Finally, the air fare allowed to verify the price fluctuation by airport and by airline. As seen in the literature review, the air fare has significance in choosing in past studies (Harvey, 1987; Ashford \& Bencheman, 1988; Hess \& Polak, 2005; 
Loo, 2008; de Luca, 2012; Murça \& Correia, 2013; Muñoz et al., 2017; Cheung et al., 2020), being a primary factor for passengers, since they tend to prefer airports that have cheaper tickets.

The utility of choosing an airport was measured by binomial logit, also known as linear probability (MPL), which considers a situation with only two possibilities of choice. The binomial logit assumes that the choice is a linear function of the explanatory variables. The biggest advantage of binary logit is its simplicity, both in interpretation and estimation (Louviere et al., 2000). Equation 4 shows the binomial logit probability between two alternatives $i$ and $j$ :

$$
P i=\frac{1}{1+e^{-(U i-U j)}}=\frac{1}{1+e^{-(U i-U j)}} \frac{e^{U i}}{e^{U i}}=\frac{e^{U i}}{e^{U i}+e^{U j}}
$$

Equation 5 reveals the relative attributes of the airport choice of a utility function:

$$
\text { Ui }=\beta 1 * \text { ALINE }+\beta 2 * \text { SATF }+\beta 3 * \text { TIME }+\beta 4 * \text { AFARE }+\beta 5 * \text { DIRF }+\varepsilon i
$$

In which:

Ui: utility function for REC;

ALINE: airline dummy;

SATF: degree of general satisfaction of the airport;

TIME: access time to reach the airport;

AFARE: average monthly fare per airline;

DIRF: flight frequency dummy;

$\beta 1$... $\beta 5$ : unknown coefficients related to the attributes;

Ei: random term of the function.

\section{Results and Discussion}

In order to analyze the percentage of choice, the data were processed in Gretl (2019) software. Data from the two airports under study were submitted year by year, with REC considered as the base airport.

Table 1 presents the results of REC's utility compared to NAT. In 2018, all passengers interviewed had direct flights, which made it impossible to use the dummy direct flight that year. 
Table 1: results from binomial logit.

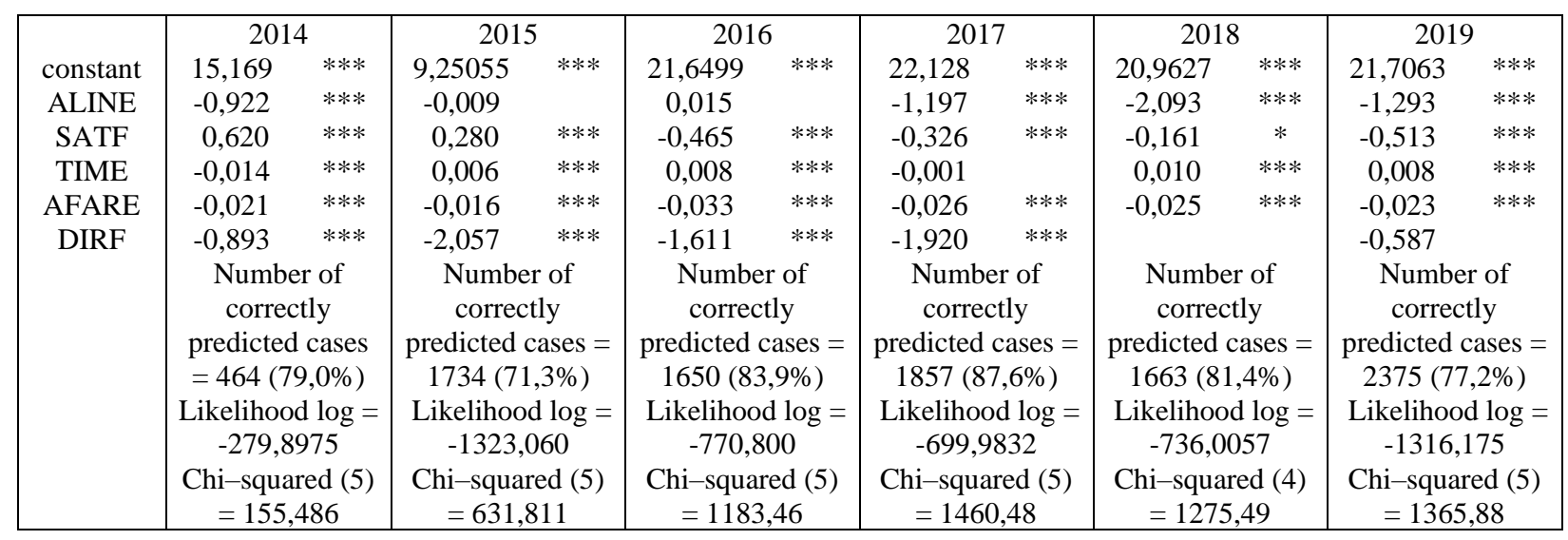

Source: Authors.

The analysis in Table 1 shows that the null hypothesis can be rejected for all variables, with the exception of ALINE in 2015 and 2016, TEMP in 2017 and DIRF in 2019 (p-value>0.100). For the t-test, all were significant ( $>$ > $1.96 \mid$ ), except for the same four variables mentioned above. Thus, excluding these variables, all presented a $5 \%$ confidence level for infinite degrees of freedom.

Table 1 shows that the TIME and SATF variables changed signs during the period. Regarding TIME, the justification for this fact is due to the inaccuracy in the response of the access time, since there is a possibility that the interviewers answered how far in advance they arrived at the airport instead of the access time itself. For SATF, it is indicated that the degree of satisfaction at REC decreased as the demand for the airport increased. The variable ALINE indicates that only in 2016, the utility favored REC, although it is not significant to represent the utility. This factor is explained by the growth of Azul Airlines flights at that airport in the year, which contributed to increase the frequency of flights.

In 2014, the signs of the coefficients indicate that only the airport's degree of satisfaction positively influenced the choice of REC. This may have happened because NAT started operating this year, and had lower fares in order to attract passengers to the newly built terminal. It can also be observed that DIRF and ALINE are negative, indicating that the existence of more service options by airlines and direct flights, attracts more passengers to NAT. Regarding TIME, the value is very low, suggesting that although negative, it is not the most relevant factor in choosing NAT this year.

The beginning of a change of scenery regarding the choice of REC due to NAT occurs in 2015. ALINE remains negative, had no significance, and therefore, it was disregarded from the analysis. TIME shows a change in signal, indicating the choice of REC. It is a factor to be considered since REC is 11 kilometers from the city center while NAT is 33 kilometers from the center of the state capital. AFARE has a lower utility compared to the previous year, but continues to indicate the preference for NAT. In addition, the value of the DIRF had a significant increase in utility when revealing the choice of NAT.

In 2016, TIME was the most relevant in the choice of REC, as it had a positive value, albeit low. The rate and availability of direct flights continue to favor NAT. The negative sign on the direct flight to the utility of REC may be due to the fact that the airport has become a hub, which indicates that many passengers connect in REC, promoting a decrease in utility. The crucial factor that year was SATF, which in previous years benefited REC, however in 2016, it became a highlight in the choice for NAT. This event is related to the fact that NAT is the most modern in the region with CUSS self-check-in system, automated luggage system and comfort and modernity in departure areas (Inframerica, 2020).

For 2017, the scenario favored the choice of NAT, where the most relevant factor was the direct flight variable. It is worth noting that, as previously mentioned, in 2017, the two airports under study showed growth in demand. The utilities for the years 2018 and 2019 are similar, in which the most significant variable in choosing NAT is the preference for airline while 
for REC, it is the time duration to access the airport.

To check the likelihood of choosing between the two airports, Table 2 and Figure 3 should be analyzed.

Table 2: Analysis of probabilities and elasticities.

\begin{tabular}{|c|c|c|c|c|c|c|}
\hline & 2014 & 2015 & 2016 & 2017 & 2018 & 2019 \\
REC & $77 \%$ & $63 \%$ & $53 \%$ & $73 \%$ & $78 \%$ & $77 \%$ \\
NAT & $23 \%$ & $37 \%$ & $37 \%$ & $27 \%$ & $22 \%$ & $23 \%$ \\
ALINE & $-0,16332$ & $-0,00208$ & 0,00365 & $-0,23457$ & $-0,35822$ & $-0,23081$ \\
SATF & 0,10983 & 0,06550 & $-0,11580$ & $-0,06392$ & $-0,02755$ & $-0,09161$ \\
TIME & $-0,00253$ & 0,00134 & 0,00208 & $-0,00011$ & 0,00166 & 0,00152 \\
AFARE & $-0,00368$ & $-0,00377$ & $-0,00823$ & $-0,00516$ & $-0,00431$ & $-0,00402$ \\
DIRF & $-0,13368$ & $-0,34666$ & $-0,32422$ & $-0,27315$ & & $-0,09141$ \\
\hline
\end{tabular}

Source: Authors.

Figure 3: comparison of probabilities and elasticities between REC and NAT.

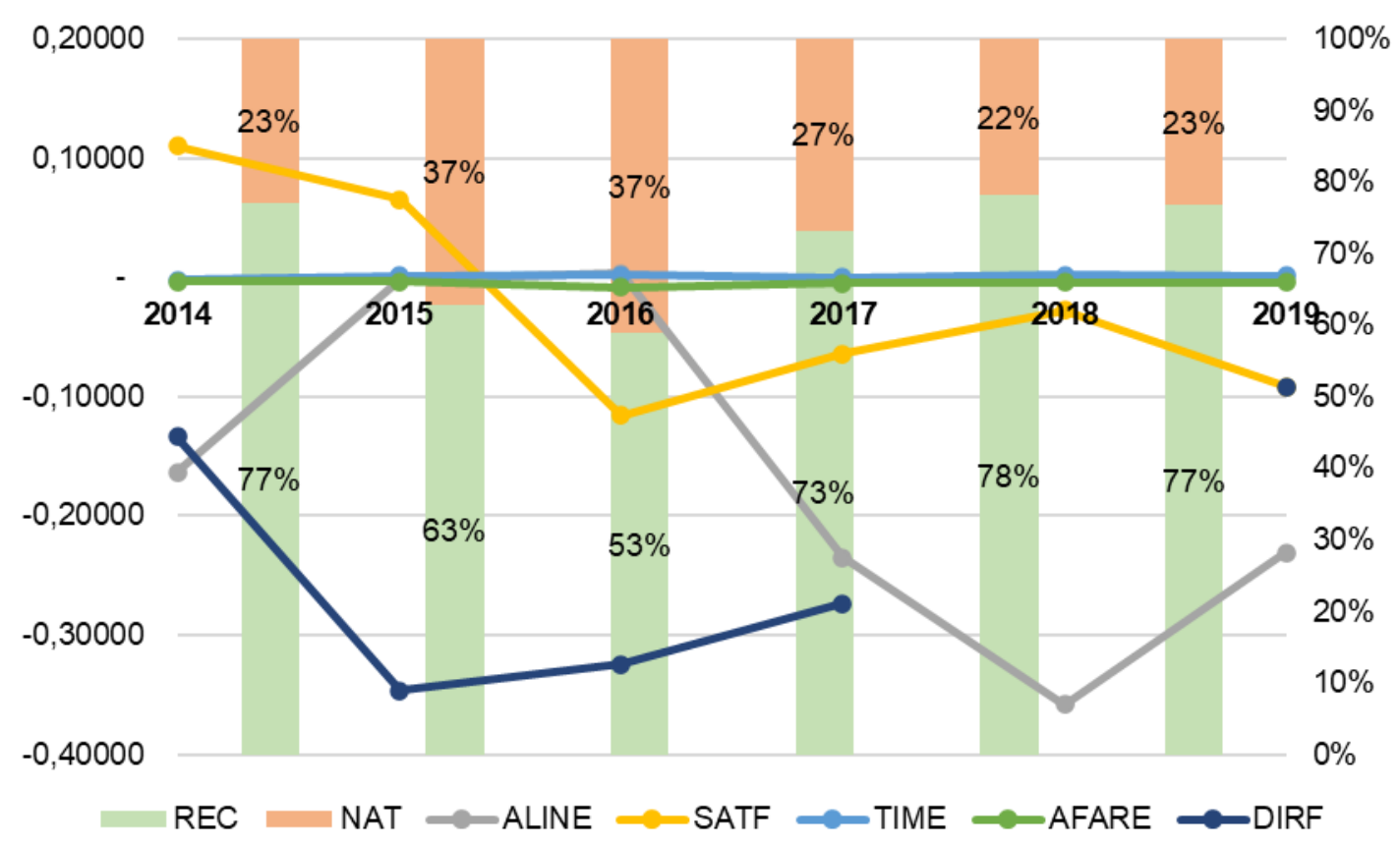

Source: Authors.

Table 2 allows to conclude that in all years of the analysis, REC has a higher probability of choice by passengers.

When evaluating the variables, it can be seen that in 2014 the presence of certain airlines had a significant importance in the choice of passengers by NAT, however in 2015 this value dropped greatly and in 2016 it became positive. It returned to rise negatively in 2017, 2018 and 2019, when it reached its highest value. Regard to satisfaction, it was positive in 2014 and in 2015. However, it became negative in 2016 and remained reasonably stable until 2019. The change of signal shows that with the increase in demand for REC, the general satisfaction with the airport decreased. This variable reached its peak in 2016 and today represents an important factor in the choice. To increase the usefulness of NAT by $1 \%$, it is necessary to increase the quality of the airport by $0.09161 \%$.

TIME had its negative value in 2014, but subsequently, with the exception of 2017, it obtained positive values, demonstrating that the increase in access time to NAT will lead to loss of attraction power. AFARE has remained negative 
over the years, evidencing the choice for NAT. The air fare was presented as an important factor in choosing this airport, and for this reason, it is important that the operator maintains these flights and the activities of the airlines in order to increase competition and decrease the ticket price. It is believed that air fare has higher values in REC due to the fact that the airport is a hub and has more long-haul destinations, making the air route more expensive.

The highest probability of choice for REC happened in 2018, with the time of access to the airport the most relevant factor. When analyzing the elasticity of this variable, it is observed that by increasing the access time to the airport by $1 \%$, the demand for NAT decreases by $0.00166 \%$. In contrast, in 2016, variables of general airport satisfaction, air fare and availability of direct flights were significant for choosing NAT. Observing the elasticities, by increasing SATF by $1 \%$, the demand for NAT increases by $0.1158 \%$. Additionally, the increase of AFARE and DIRF by $1 \%$ results in an increase of the demand for NAT by $0.00823 \%$ and $0.32422 \%$, respectively.

For 2019, the probability of choosing REC is 77\%, mainly due to TIME. AFARE, SATF and DIRF have minimal influence on the choice of NAT. The most relevant factor for this airport is ALINE.

Finally, the analysis in Figure 3 reveals that SATF was the most fluctuating variable during the study period, indicating that it influences the choice of a terminal by passengers. Thus, to increase the movement, the concessionaires must invest in resources to improve the performance of this factor.

Regarding the state's economy, Natal is known for tourism and Recife for business. This favors the growth of flights to REC, since tourism in Natal is considered seasonal (Medeiros, 2007). In addition, as previously mentioned, 3,279 of the passengers with business reasons started their flight in Recife and 595 in Natal. Passengers with business travel reasons are expected to be less susceptible to fare price increases.

In general, the variable availability of direct flight favors the choice by NAT and that the time of access to the airport favors the choice by REC. Many studies corroborate with these variables, including Hess and Polak (2005) and de Luca (2012). Hess and Polak (2005), when studying the choice of the airport by passengers departing from the San Francisco Bay area, reported that access time, frequency and air fare were important factors, however, with deterministic variations between groups of travelers (business and leisure). When assessing competition between three airports in the Region of Campania (Italy), de Luca (2012) stated that among the variables studied, access time is the most significant in the choice of a terminal by passengers. In addition, the air fare is likely to change in the market shares of the airports, but would require a wide variation.

\section{Conclusion}

The present study aimed to evaluate the choice by passengers between Natal International Airport (NAT) and Recife International Airport (REC). For the analysis of the coefficients, elasticities and probabilities, the binomial logit model was used. The database was built using the Revealed Preference Technique and embraces factors such as airport access time, choice of airline, average monthly air fare, availability of direct flights and general satisfaction of the airport.

The interpretation of the results allowed to verify that between 2014 and 2019, REC had a greater probability of choice compared to NAT. The highest probability occurred in 2018, with $78 \%$ preference. In that year, access time to the airport was the most significant factor in choosing this terminal.

In general, air fare and the time of access to the airport varied slightly while overall satisfaction of the airport, choice of airline and availability of direct flights fluctuated over the years. The most significant variable was the general level of satisfaction at the airport, indicating that it was essential for passengers to choose a terminal. Thus, it is a factor that demands investment to attract passengers.

It can also be mentioned that, in general, air fare variable favors the choice by NAT. It is believed that air fare has higher values due to the fact that REC is a hub and has more long-haul destinations, making the air route more expensive. In 
addition, Recife is known for business and Natal for seasonal tourism, which can indicate that business travelers tend to be less susceptible to an air fare price increase. In order to NAT compete with REC, it is important that the operator maintains the flights and the activities of the airlines in order to increase competition and decrease the ticket value.

The access time to the airport favors the choice of REC by passengers. This is mainly because REC is closer to the city center compared to NAT. To increase the general attractiveness of NAT, it would be ideal to introduce a bus service in partnership with the airline or the airport concessionaire, connecting a central point in the city of Natal to the airport, in order to make the access time less problematic.

Additionally, the theme of the two-sided platform is reinforced, which indicates that the quality of service proposed by airports through the quality of service, availability of cutting-edge technology and comfort and modernity in the lounges and departure areas are fundamental for choosing both airlines and commercial sectors, which attracts passengers. Therefore, this article offers a contribution to the academic literature and also to airport operators in the context of passenger inclinations regarding the services offered by airports.

Possible future work can be developed from this theme, such as, conducting research through the Declared Preference Technique, applying other methods of discrete choice and checking the heterogeneity in the choice based on the difference between the profiles of passengers due to the reason of travel (business and leisure).

\section{References}

Aena Brasil (2020). Characteristic of the airport. Website do Aerorporto Internacional de Recife - Guararapes - Gylberto Freire. https://www.aenabrasil.com.br/pt/aeroportos/aeroporto-internacional-do-recife-guararapes-gilberto-freyre/index.html.

ANAC (2019a). Historical and operational data of the airports. Website of Agência Nacional de Aviação Civil (ANAC). https://www.anac.gov.br/assuntos/paginas-tematicas/concessoes

ANAC (2019b). Air fares. Website of Agência Nacional de Aviação Civil (ANAC). https://www.anac.gov.br/assuntos/paginas-tematicas/concessoes.

Ashford, N. \& Benchemam, M. (1987). Passengers' Choice of Airport: an Application of the Multinomial Logit Model. Transp. Res. Rec., 1-5.

Bao, D., Hua, S. \& Gu, J. (2016). Relevance of airport accessibility and airport competition. J. Air Transp. Manag., (55), 52-60.

Ben-Akiva, M. E. \& Lerman, S. R. (1985). Discrete Choice Analysis: Theory and Application to Travel Demand. MIT Press.

Bettini, H.F.A.J. \& Oliveira, A.V.M. (2016). Two-sided platforms in airport privatization. Transp. Res. Part E Logist. Transp. Rev., (93), 262-278.

Cheung, T.K.Y., Wong, W. hung, Zhang, A. \& Wu, Y. (2020). Spatial panel model for examining airport relationships within multi-airport regions. Transp. Res. Part A Policy Pract., (133), pp. 148-163.

De Luca, S. (2012). Modelling airport choice behaviour for direct flights, connecting flights and different travel plans. J. Transp. Geogr., (22), $148-163$.

EPL (2015). Relatório o Brasil que voa. www.aviacao.gov.br/obrasilquevoa.

Gatwick Airport (2010). Two-sided platforms and airports. https://www.gatwickairport.com/globalassets/publicationfiles/business_and_community/reg ulation/competition/doc29-galtwo-sidedplatformspaper.pdf.

Great Circle Mapper (2020). Global map. http://www.gcmap.com/mapui?DU=mi.

Gretl (2019). GNU Regression, econometric and time-series library (Gretl), Cottrell, A., Lucchetti, R. http://gretl.sourceforge.net/.

Harvey, G. (1987). Airport choice in a multiple airport region. Transp. Res. Part A Gen., (21), 439-449.

Hess, S. \& Polak, J.W. (2005). Mixed logit modelling of airport choice in multi-airport regions. J. Air Transp. Manag., (11), 59-68.

ICAO (2018). Aviation trends. International Civil Organization. https://www.icao.int/annual-report-2018/Documents/Annual.Report.2018_Air\%20Tr ansport\%20Statistics.pdf.

Inframerica (2020). Historical data of NAT. https://www.natal.aero/br/.

Jarach, D. (2001). The evolution of airport management practices: towards a multi-point, multi-service, marketing-driven firm. Journal of Air Transport Management, (7), 119-125.

Jimenez, E. (2014). Airport strategic planning in the context of low-cost carriers ascendency: insights from the European experience. Doctoral Program in Transportation Systems, MIT Portugal Program. 
Jimenez, E., Claro, J. \& Sousa, J.P. (2014). The Airport Business in a Competitive Environment. Procedia - Soc. Behav. Sci., (111), 947-954.

Kalakou, S. \& Macário, R. (2013). An innovative framework for the study and structure of airport business models. Case Stud. Transp. Policy, (1), 2-17.

Lieshout, R. (2012). Measuring the size of an airport's catchment area. J. Transp. Geogr., (25), $27-34$.

Loo, B. P. Y. (2008). Passengers' airport choice within multi-airport regions (MARs): some insights from a stated preference survey at Hong Kong International Airport. J. Transp. Geogr., (16), 117-125.

Louviere, J. J., Hensher, D. A. \& Swait, J. D. (2000). Stated choice methods. Cambridge University Press.

Medeiros, A. (2007). Turismo de eventos como estratégia no combate à sazonalidade: uma análise na hotelaria de Natal-RN. Master Program - Universidade Federal do Rio Grande do Norte.

Muñoz, C., Cordoba, J. \& Sarmiento, I. (2017). Airport choice model in multiple airport regions. J. Airl. Airpt. Manag., (7), 1.

Murça, M. C. R. \& Correia, A. R. (2013). Análise da modelagem da escolha aeroportuária em regiões de múltiplos aeroportos. Journal of Transport Literature, (4), pp. 130-146.

Negri, N.A.R., Borille, G.M.R. \& Falcão, V.A. (2019). Acceptance of biometric technology in airport check-in. J. Air Transp. Manag., (81).

Pagliari, R. \& Graham, A. (2019). Airport competition within the Scottish lowlands region. Res. Transp. Econ.

Paliska, D., Drobne, S., Borruso, G., Gardina, M. \& Fabjan, D. (2016). Passengers' airport choice and airports' catchment area analysis in cross-border Upper Adriatic multi-airport region. J. Air Transp. Manag., (57), 143-154.

PAN (2019). Plano Aeroviário Nacional. https://infraestrutura.gov.br/conteudo/52-sistema-de-transportes/8110-plano-aeroviario-nacional.html.

Pels, E., Nijkamp, P. \& Rietveld, P. (2001). Airport and airline choice in a multiple airport region: An emphirical analysis for the San Francisco bay area. Reg. Stud., (35), pp. 1-9.

Pereira, A.S., Shitsuka, D.M., Parreira, F.J. \& Shitsuka, R. (2018). Metodologia da pesquisa científica. UFSM. https://repositorio.ufsm.br/bitstream/handle/1/15824/Lic_Computacao_Metodologia-Pesquisa-Cientifica.pdf?sequence=1 .

Prentice, C. \& Kadan, M. (2019). The role of airport service quality in airport and destination choice. J. Retail. Consum. Serv., (47), 40-48.

SAC (2020). Historical data. Secretaria de Aviação Civil. Website Hórus. Ministério dos Transportes, Portos e Aviação Civil. https://horus.labtrans.ufsc.br/gerencial/\#Movimentacao/Ranking.

SIROS (2020). Historial data. Consulta de voos planejados - SIROS. https://sas.anac.gov.br/sas/siros/(S(vlc2bsso5ftnrtjohiv 213if))/view/registro/frmConsultaVoos.

Skinner, R. E. Jr. (1976). Airport choice: an empirical study. Transp. Engrg. J., ASCE, 102(4), 871-882.

Train, K. E. (2003). Discrete choice methods with simulation. Cambridge University Press.

Tretheway, M. \& Kincaid, I. (2005). Competition between airports in the new Millennium: what works, what doesn't work and why. 8th Hambg. Aviat. Conf., $1-18$.

Website Hórus (2019a). Historical data. https://horus.labtrans.ufsc.br/gerencial/.

Website Hórus (2019b). Historical data. https://horus.labtrans.ufsc.br/gerencial/\#DesempenhoOperacional/DadosCompletos .

Windle, R. \& Dresner, M. (1995). Airport choice in multiple-airport regions. J. Transp. Eng., (121), 332-337. 